\title{
Uzun Nakliyat Araçlarının Kullanımına Uygun A Tipi Orman Yolu Planlanacak Geçkilerin Belirlenmesi: Küre Orman İşletme Şefliği Örneği
}

\author{
"Çiğdem ÖZER GENÇ ${ }^{1}$, Burak ARICAK ${ }^{1}$ \\ ${ }^{1}$ Kastamonu Üniversitesi, Orman Fakültesi, Orman Mühendisliği Bölümü, Kastamonu \\ *Sorumlu yazar: cozer@kastamonu.edu.tr
}

Geliş Tarihi: 02.11.2016

\begin{abstract}
Özet
Sürekli ve rasyonel ormancılığın en önemli araçlarından biri olan orman yol ağları, ormancılığın amaç ve hedefleri doğrultusunda orman alanını eşit ve yeterli oranda işletmeye açmalıdır. Planlanacak orman yol ağları ormanın genel işletme amacına uygun, ekolojik dengeyi göz önünde bulunduran, üretim yeri ile depo arasında en uygun ve kısa bağlantıyı kuracak şekilde planlanmalıdır.

Ülkemizde orman alanlarından çok amaçlı faydalanmayı sağlamak için fonksiyonel tabanlı amenajman planları yapılmaktadır. Buna rağmen bu planların başarıya ulaşmasında en önemli altyapı tesisi olan orman yollarının planlamasında değişik amaçlar için bir yol planlama yaklaşımı gerçekleştirilmemiştir. Bu nedenle farklı fonksiyonlara hizmet edecek orman yol ağlarının da fonksiyonel planlama esaslarına göre yeniden düzenlenme gereği ortaya çıkmaktadır. Günümüzde üretim fonksiyonuna sahip ormanlardan orman ürünlerinin tüketicilerin istekleri doğrultusunda farklı boyutlarda da çıkarılabilmesi mümkün olabilmektedir.

Yapılan çalışmada Küre Orman İşletme Şefliğinde bütün gövde üretimine konu olabilecek meşcereler belirlenmiş, bu alanlardan uzun boylu emvallerin transportu ve tek seferde daha fazla emvalin taşınması için tır tipi nakliyat araçlarının kullanımına uygun A Tipi orman yolu olarak planlanabilecek geçkiler tespit edilmiştir. Bunun için üretime konu meşcerelerden ana yola yakın (asfalt üstyapıya sahip yollardan $1000 \mathrm{~m}, 1500 \mathrm{~m}, 2000 \mathrm{~m}$ kuş uçuşu mesafede) olup bütün gövde formunda üretimin yapılabileceği meşcereler belirlenmiş, bu meşcereleri işletmeye açma amacıyla mevcut veya planlanmış B Tipi orman yollarının A Tipi orman yolu standartlarında yükseltilecek geçkileri ArcGIS ortamında planlanmıştır.

Anahtar Kelimeler: Orman yolu planlama, A Tipi orman yolu, Bütün gövde transportu, Uzun nakliyat arac1

\section{Determination of Routes as Type-A Forest Roads for Long Haulage Vehicles: Küre Forest Sub- District Directorate}

Abstract

Forest road networks which are one of the most important tools of continuous and rational forestry should put into operation to forest area equal and adequate in line with the objectives of forestry. Forest road network that will be planned should be planned in accordance with the general management objectives of the forests, taking into consideration the ecological balance, to establish the most appropriate and short connection between storage and production place.

In our country, functional-based forest management plans are carried out to provide multi-purpose utilization from forest areas. Even so, a road planning approach hasn't been carried out for different purposes in planning of forest roads that is most important infrastructure facilities performing in success of forest management plans. Therefore, the necessity of the reorganization of forest road network according to the functional planning principles to be serve different functions have arised. Nowadays, in accordance with demands of consumers forest products which are producted in certain standard can also be removed in different sizes from the forest with production functions.

In the study, determined stands to be subject to whole log production, routes to be planed as type - A forest road that are suitable for use transportation vehicles with multi-wheeled truck type were determined to transportation of tall $\operatorname{logs}$ and removal more $\log$ at a time this the areas. Thus, stands are that the production can be made as whole log the form and also close to the main road $(1000 \mathrm{~m}, 1500 \mathrm{~m}, 2000 \mathrm{~m}$ air distance from roads with asphalt superstructure) were determined. In order to exploit to stands, routes of existing or planned B-type secondary forest roads that will be upgraded to A-type secondary forest roads the standards were planned in ArcGIS environment.
\end{abstract}

Key Words: Forest road planning, Type-A forest road, Whole log transport, Long-haulage vehicles 


\section{Giriș}

Orman ürünlerinin taşınmasında kullanılan transport tesislerinden ilk başta geleni orman yolları olup hem ormancılik hem de ormancılık dışı faaliyetlerde uzun süreli kullanılabilmektedir (Çağlar ve Acar 2005). Orman yollarının optimal şekilde planlanmas1 ve yapımı, ormancilık çalışmalarının daha verimli, güvenli, etkin ve yararlı bir şekilde yapılmasını sağlamaktadır (Anon. 2002). Orman yolları kullanım amaçlarına göre; ormancılık uygulamalarını gerçekleştirmek, orman içi köylere ve tesislere (barınak, avlanma tesisleri, av ve yaban hayvanı üretim yeri, turistik tesisler vs.) ulaşım sağlamak gibi kullanım alanlarına hizmet etmektedir (Tavsanoglu, 1973; Potocnic, 1996).

Planlanacak yol güzergahlarının belirlenmesinde; ormanların çok yönlü fonksiyonel faydalarına yüksek seviyede hizmete sunacak, orman içi ve bitişiği alanlarda yaşayan insanların kalkınmasına ve yaşantısına katkı sağlayacak, ormanlık alan kaybını en aza indirecek, sürekli ve güvenli ulaşıma açık kalabilecek, yapım ve bakım maliyeti en düșük, çevre zararı en az olan yolların planlanmasi temel ilkedir. Her mühendislik çalışmasında olduğu gibi yol planlama ve yapımında da doğaya uygun, emniyetli ve ekonomik olma koşullarının sağlanması gerekmektedir. Emniyetli olma koşulunun yerine getirilmesi için yolların gerekli olan standartlarda inşa edilmesi gerekmektedir. (Hasdemir ve Demir, 2000).

Ülkemizde orman yol ağları planlanırken ormanların en önemli fonksiyonu olan üretim fonksiyonu göz önünde bulundurulmaktadır. Ancak orman yol şebeke planları yapılırken ormanların sadece üretim fonksiyonu değil tüm fonksiyonları dikkate alınmalıdır (Gumus ve ark., 2008). Pentek (2007) belli siniflara ayrilan orman yollarının teknik özelliklerini tanımlamaya çalışarak yüksek kategorideki kamyon yollarının (yüksek trafik hacmine sahip olanlar) daha yüksek standartlarda inşa edilmesi gerektiğinin üzerinde durmuştur.

Türkiye'de orman yolları geometrik standartları, bir yılda üzerinde taşınacak emval miktarları, yapılış amaçları, trafik yoğunluğu, seyir halindeki araçların büyüklüğü ve tonajları dikkate alınarak üç ana gruba ayrılmıştır (OGM, 2008). Bunlar ana orman yolları, tali orman yolları ve traktör yolları olup aynı zamanda da Türkiye'de orman yollarının uygulamadaki yol tiplerini oluşturmaktadır. $\mathrm{Bu}$ yolların hendek ve yol genişlikleri, bir yılda taşınacak emval miktarları, kurp yarıçapları, eğim yüzdeleri, vb. teknik özellikleri farkl1 değerler arz etmektedir (Tablo 1). Bu geometrik özellikler; orman yolu planlamasinda, projelendirilmesinde ve inşaatında gözetilmesi gereken azami ve asgari standartları ifade etmektedir.

Tablo 1. Orman yolları geometrik standartları (OGM, 2008)

\begin{tabular}{|c|c|c|c|c|c|c|c|}
\hline \multirow{3}{*}{ Yolun Tipi } & \multirow{3}{*}{ Birimi } & \multirow{3}{*}{$\begin{array}{l}\text { Ana } \\
\text { Orman } \\
\text { Yolu }\end{array}$} & \multicolumn{4}{|c|}{ Tali Orman Yolu } & \multirow{3}{*}{$\begin{array}{l}\text { Traktör } \\
\text { Yolu }\end{array}$} \\
\hline & & & \multirow{2}{*}{ A - TíPİ } & & \multicolumn{2}{|c|}{ B - TİPI } & \\
\hline & & & & SBT & NBT & EBT & \\
\hline Platform genişliği & $\mathrm{m}$ & 7 & 6 & 5 & 4 & 3 & 3,5 \\
\hline Şerit sayısı & Adet & 2 & 1 & 1 & 1 & 1 & 1 \\
\hline Azami eğim & $\%$ & 8 & 10 & 9 & 12 & 12 & 20 \\
\hline Asgari kurp yarıçap1 & $\mathrm{m}$ & 50 & 35 & 20 & 12 & 8 & 8 \\
\hline Şerit genişliği & $\mathrm{m}$ & 3 & 3 & 3 & 3 & 3 & 3 \\
\hline Banket genişliği & $\mathrm{m}$ & 0,50 & 0,50 & 0,50 & 0,50 & 0.50 & \\
\hline Hendek genişliği & $\mathrm{m}$ & 1,00 & 1,00 & 1,00 & 1,00 & 0.50 & \\
\hline Üst yap1 genişliği & $\mathrm{m}$ & 6 & 5 & 4 & 3 & 3 & \\
\hline Köprü genișliği & $\mathrm{m}$ & $7+(2 \times 0,6)$ & $6+(2 \times 0,6)$ & & $2 \times 0,6)$ & $4+(2 \times 0,6)$ & \\
\hline
\end{tabular}

Ülkemizde orman yollarının büyük çoğunluğu "B Tipi Orman Yolu" standardında yapılmakta olup (Şekil 1a), ortalama yol genişliği platform ve hendekle birlikte 5 m'dir. Bu yollar üzerinde bir yılda taşınacak emval miktarı $25000 \mathrm{~m}^{3}$ 'ten azdır. 
"A Tipi Orman Yolları", trafik șeridi genişliği $6 \mathrm{~m}$ ve kenar hendeği genişliği $1 \mathrm{~m}$ olmak üzere toplam genişliği $7 \mathrm{~m}$ olan ana yollardır (Şekil 1b). Bu tip yolların yapımı için yol üzerinde bir y1lda taşınacak odun hammaddesi miktarının $25000-50000 \mathrm{~m}^{3}$

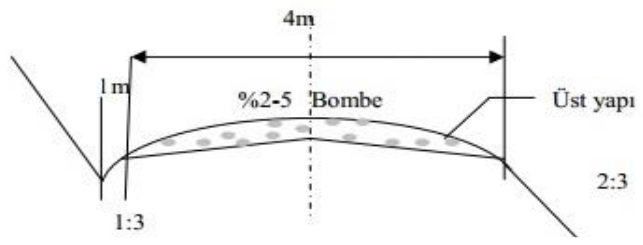

Şekil 1. B Tipi orman yolu (a) ve A Tipi orman yolu (b) (Erdaş, 1997)

Günümüzde orman ürünü alıcısının ürüne çabuk ulaşma isteği ve üretilen ürünün bölmeden çıkarma - transportu sırasındaki aşamalarda göreceği zararın en aza indirilmesi gerekliliği karşısında, orman yolları standartlarının iyileştirilmesi üzerinde durulması gereken konu haline gelmiştir. Ormanlık alanlarda planlanan orman yol geçkilerinin standartları farklılık gösterebilmektedir. Standartları düşük olan yolların yapım giderleri düşük, bakım giderleri yüksektir. Yüksek standarttaki yollarda ise yapım giderleri yüksek, bakım giderleri düşüktür. (Erdaş, 1997). Mevcut B Tipi orman yollarının standartları göz önünde bulundurulduğunda, uzun ve taşıma kapasitesi yüksek araçlar için manevra kabiliyetini ve kurp geçişlerini sınırlayan durumlar göze çarpmaktadır. A Tipi orman yollarının geometrik standartları B Tipi orman yollarına göre yüksek olup bütün yıl boyunca kamyonla uzun tomrukların nakliyatına uygun kaplama yollardır (Görcelioğlu, 2004). Üretim ormanlarında kamyon-treyler türü nakliyat araçlarının hareketlerine uygun olan A Tipi orman yolları için eğim, kurp yarıçapı ve üst yapı durumu yeterlidir. A Tipi orman yolları taşıma hızı, taşıma zamanı, toplam taşıma masrafları açısından B Tipi orman yollarına nazaran daha avantajlıdır.

Odun hammaddesinin üretimi sırasında arazi şartları, bölmeden çıkarma teknikleri, piyasa istekleri gibi durumlar üretim metodunu ve tomruk boyutlarının standartlarını belirlemektedir. Ormancılık arasinda olması ve Orman Genel Müdürlügü̈nden özel izin alınmas1 gerekmektedir. Bu yollarda üstyapı genişliği $5 \mathrm{~m}$, en küçük kurp yarıçap1 $35 \mathrm{~m}$ ve maksimum eğim değeri ise \% 10'dur (OGM, 2008).

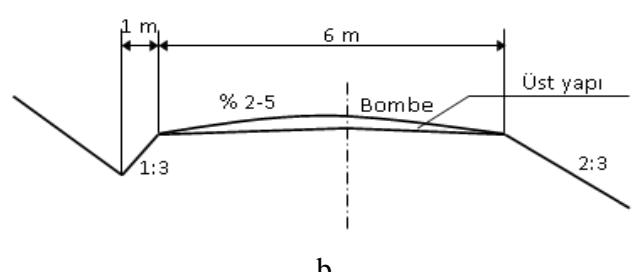

sektöründe belirli uzunluklarda üretilen tomruklar bugün artık tüketicilerin isteklerini karşılayamaz duruma gelmiştir. Dolayısıyla tır gibi uzun, birden fazla aksa sahip, çok tekerlekli ve yüksek kapasiteli nakliyat araçlarının orman ürünlerinin transportunda kullanılmasıyla daha uzun, hatta bütün gövde halinde ürünlerin nakliyatı söz konusu olabilmektedir. Bütün gövde metodu, üretim sahası içinde ağacın devrilmesi, tepesinin 12 cm'den küçük olan kısmının kesilmesi ve alt dallarının alınmasıyla yol kenarlarına veya toplama noktalarına sürütüldükten sonra buralardan depolara ya da direk piyasaya transportunun yapıldığı bir üretim metodudur. $\mathrm{Bu}$ üretim metodu; üretim alanlarından tek seferde daha çok ürünün çıkartılmasını sağlamakta ve ürünlerde daha az zayiatla değer kaybını minimize etmektedir. Ayrıca birim zamanda iş verimi yükseleceği için işletme daha fazla kazanç sağlamakta, işçi sayısının azalmasıyla ișletme karlılığ 1 artmakta, iș kazası riski azalmakta, kesim ile satı̧ arasındaki süre kısalmakta ve daha az harcanan zamanla beraber transport verimliliği de artmaktadır (Erdaş ve ark., 2014; Akgül, 2007; Öztürk, 2006).

Borre ve Larsson (2011) uzun tırların (Long vehicle) genellikle iki veya üç bağlantı noktasına sahip, maksimum uzunluğu $25 \mathrm{~m}$ olan uzun nakliye araçları olduğunu belirtmişlerdir (Şekil 2). Klasik nakliye araçlarının yük kapasite hacmine göre uzun tırların römorkları üzerinde kullanılan konteynerin daha yüksek olmasından dolayı 
\%50 daha fazla ürün taşıma hacmine sahip olduğunu vurgulayarak bir tırın üç adet klasik nakliye taşıtının toplam hacim kapasitesinde olduğunu vurgulamışlardır. Ayrıca büyük tırların 60 tona kadar ağırlık taşınabildiklerini ve bu araçların uygun standarttaki yollar üzerinde hareket etmek zorunda olduğu üzerinde durmuşlardır. Bunların yanı sıra yapmış oldukları çalışmada daha az harcanan zamanla beraber transport verimliliğinin

arttığını, kaza sayılarında ve riskinde düşüş olduğunu, taşıtlardaki yıpranma ve bozulmalarda azalma görüldüğünü, yakıt tüketiminde azalma olduğunu belirlemişlerdir.
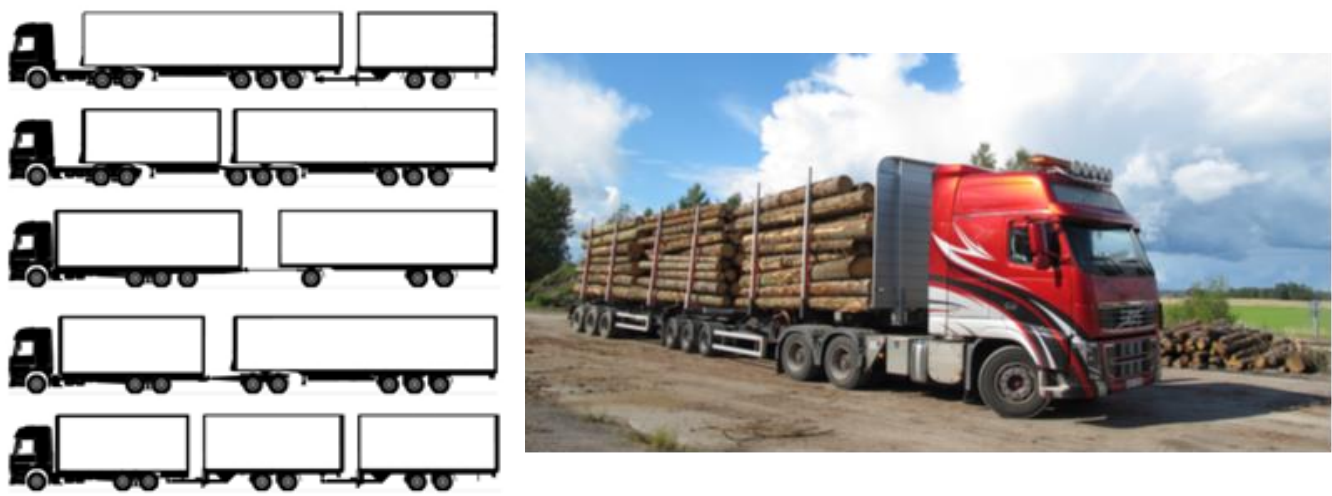

Şekil 2. Tomruk taşımacılığı için kullanılan faklı tiplerdeki uzun tır (long vehicle) örnekleri

Giummarra ve Blanksby (2006) uzun nakliye araçlarının kullanıldığı tomruk taşımacılığında yollar için belirlenmesi gereken önemli faktörlerin; yol sinıflarının taşıt tiplerine uygunluğu, kavşakların tasarım1, dar virajlarda yol geometrisinin tomruk kamyonlarıyla uyumu, güzergâhtaki dar virajların genişliği, görüş uzaklığ koșulları, yön ișaretleri, üstyapı planlaması olduğunu belirterek bu sayede yapilan nakliyatın daha ergonomik ve güvenilir olacağına dikkat çekmiştir.

Melemez ve ark. (2011) Coğrafi Bilgi Sistemi (CBS) ve Küresel Konum Belirleme Sistemi entegrasyonu ile yol güzergâhlarına ilişkin yol şebeke planlarının güncel ve doğru şekilde, konumsal ve nümerik bilgileri toplanarak, orman ișletme şefliği bazında örnek bir yol bilgi sistemi oluşturulmasını ele almışlardır. Gümüş (2003) yapmış olduğu çalışmada değişik fonksiyonlara sahip ormanların ișlevlerini yerine getirebilmesi için CBS yardımıyla bu fonksiyonlara uygun orman yol ağı planlamayı amaçlamıştır. Arıcak ark. (2007) orman yolu güzergâhının uzaktan algilama verileri ve CBS ile planlanmasiyla; orman yolu yapımı öncesinde ve yapımından sonra alınacak uydu görüntülerinin karşılaştırılması ile orman yollarının inşaat öncesi çevreye verdikleri muhtemel zararı ortaya koyulabileceğini belirtmişlerdir. Ayrıca orman yolu inşaatının zarar vereceği alanın önceden hesaplanarak ormana en az zarar veren yol geçki alternatifinin uygulanmasının hem ormanın sürdürülebilirliğinin sağlanması hem de üretimde verimliliğin artırılması açısından önemli olduğunu vurgulamışlardır. Gulci ve Akay (2015), yaban hayatı yaşam alanlarını göz önüne alarak ekolojik yol yapılarının planlanmasında CBS tabanlı çoklu kriter değerlendirme metotlarını kullanmıştır. Ayrıca, CBS tabanlı çoklu kriter değerlendirme metotları kullanılarak, mevcut yol durumunun da değerlendirildiği; turizm, yaban hayat,, ekolojik kullanımlar vb. belirlemeyi amaçlayan çalışmalar da yapılmıştır (Cetin, 2015; Brooks ve Cetin, 2013; Cetin ve Sevik, 2016).

Ormanın her yerine standardı yükseltilmiş orman yollarının planlanması hem ekonomik hem de ekolojik açıdan doğru bir uygulama olmayacaktır. Bu çalışmada Küre Orman İşletme Şefliği içerisinde bulunan veya yapımı planlanmış olan B Tipi orman yollarından; 
- piyasanın bütün gövde talebini karşılayabilmek,

- uzun boylu emvalleri taşıyabilmek,

- tek seferde daha fazla ürünün transportunu sağlayabilmek, vb.

için çok tekerlekli - yüksek taşıma kapasiteli tırların kullanımına imkân veren A Tipi orman yolu standardına yükseltilmesi tavsiye edilen yol geçkilerini belirlemek amaçlanmıştır.

Böylelikle Küre Orman İşletme Şefliğindeki hangi B Tipi orman yolu geçkilerinin A Tipi orman yolu standartlarına yükseltilerek uzun - geniş - yüksek taşıma kapasiteli tırların geçişine izin veren standartta yapılması gerektiği bu çalışma ile belirlenmiştir.

\section{Materyal ve Yöntem \\ Materyal}

Çalışma alanı olarak Kastamonu Orman Bölge Müdürlüğü, Küre Orman İşletme Müdürlüğü'ne bağlı Küre Orman İşletme Şefliği seçilmiştir. Küre Orman İşletme Şefliği; coğrafi konum itibarıla $41^{\circ} 42^{\prime} 58^{\prime \prime}$ - $41^{\circ} 52^{\prime} 40^{\prime \prime}$ kuzey enlemleri ile 3342'22'3336'03'" doğu boylamları arasındadır. İşletme Şefliğinin orman amenajman planına göre toplam ormanlık alanı 16 207,4 ha'dır. 2011 yılında yapılan yol şebeke planına göre şeflikte toplam $371+123 \mathrm{~km}$ yol bulunup, bu yollarin $251+291 \mathrm{~km}$ 'si B Tipi orman yoludur (Anonim, 2011a).

Araştırma konusunu oluşturan orman yollarına ait bilgilerin temini ve ArcGIS veri tabanının kurulması için şefliğe ait "Küre İşletme Şefliği Orman Yol Ağı Planı" kullanılmıştır. Çalışma alanındaki ormanlık alana ait veri ve bilgi temini için Orman Amenajman Planı'nda (Anonim, 2011b) yer alan meşcere haritasından yararlanılmıştır. Alana ait yol ağ planı ve alanın ormanlık alan durumu Şekil 3'de verilmiştir. Bütün gövde metodu ile üretime konu olabilecek meşcerelerin belirlenmesi, bu alanlardan emvallerin transportu için uzun nakliyat araçlarının kullanımına uygun A Tipi orman yollarının seçilmesi ve haritalanmasında ArcGIS 10.0 yazılımından yararlanılmıştır.

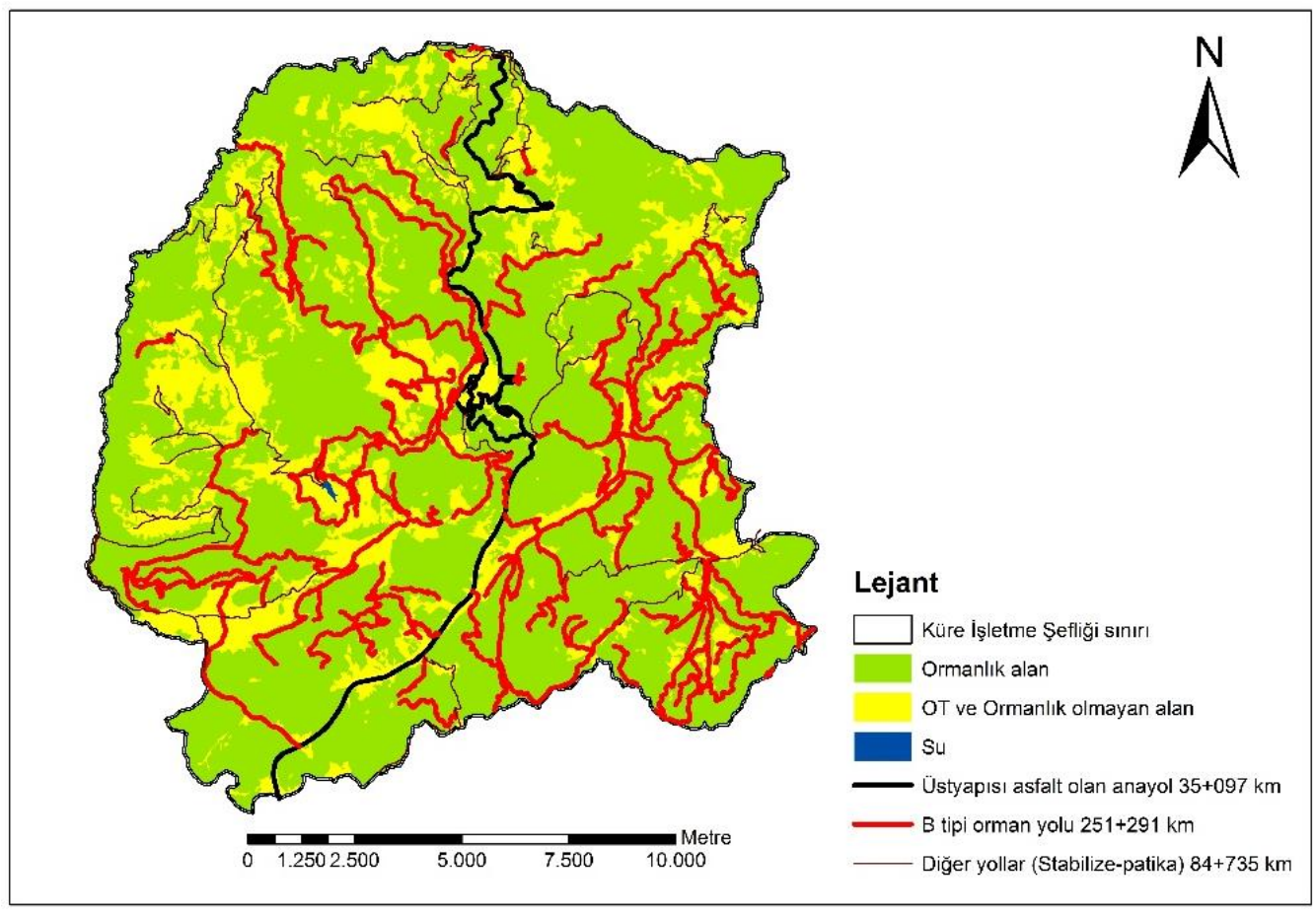

Şekil 3. Küre Orman İşletme Müdürlüğü ormanlık alan durumu ve yol ağı haritası

\section{Yöntem}

Küre Orman İşletme Şefliğinde tır tipi nakliyat araçlarının kullanabilmesi için yapımı tamamlanmış veya planlanmış B Tipi orman yollarından A Tipi orman yolu standartlarına yükseltilecek geçkilerin 
belirlenmesi amacı ile öncelikle bütün gövde üretimine konu olabilecek meşcereler belirlenmiştir.

Bütün gövde üretimine konu olabilecek alandaki boniteti yüksek, boylu ve $\mathrm{d}_{1.30}$ çap1 kalın olan meşcere tiplerini tespit etmek amacı ile "c", "cd", "d" çağındaki meşcere tipleri Küre İşletme Şefliği Meşcere Haritası kullanılarak belirlenmiştir.

İşletme Şefliği sınırları içerisinden geçen ve üzerinde her türlü büyüklükte lastik tekerlekli, uzun, geniş, römorklu kamyonların ve tırların gidebileceği, üst yapıs1 asfalt olan yollar ArcGIS ortamında belirlenmiştir. Üst yapısı asfalt olan bu yolların her iki yanlarına ayrı ayrı olmak üzere $1000 \mathrm{~m}, \quad 1500 \mathrm{~m}$ ve $2000 \mathrm{~m}$ genişliğinde tampon alanlar ArcGIS ortamında oluşturulmuştur.

Oluşturulmuş üç ayrı alan boniteti yüksek, boylu ve $d_{1.30}$ çapı kalın meşcere tipleri olan "c", "cd", "d" çağındaki meşcere alanları ile çakıştırılmıştır. $\mathrm{Bu}$ alan içerisinde bulunan yapımı tamamlanmış ve planlanmış B Tipi orman yolları da veri tabanında belirlenmiștir.

Böylelikle her üç ayrı tampon alan (asfalt üstyapıya sahip yollardan $1000 \mathrm{~m}, 1500 \mathrm{~m}$ ve 2000 m kuş uçuşu mesafe içerisinde kalan) içerisinde kalan ve hedef meșcere tiplerini işletmeye açmayı sağlayan B Tipi orman yolu uzunluk ve güzergâhları ArcGIS ortaminda belirlenmiştir.

Bütün gövde üretimine konu olabilecek meşcerelerden uzun boylu emvallerin transportu ve tek seferde daha fazla emvalin taşınması için çok tekerlekli tır tipi nakliyat araçlarının kullanımına uygun A Tipi orman yolu olarak planlanabilecek B Tipi orman yolu geçkileri bu yöntem ile üç ayrı tampon için ayrı ayrı belirlenmiştir.

\section{Bulgular ve Tartışma}

Küre Orman İşletme Şefliği yol ağ planına göre İşletme Şefliği içerisinde toplam $371+123 \mathrm{~km}$ yol (asfalt yol-orman yolustabilize yol-patika yol) bulunup bu yollarm $35+097 \mathrm{~km}$ 'si üst yap1s1 asfalt olan ana yollardan, 251+291 km'si B Tipi orman yollarından oluşmaktadır (Şekil 4). Küre Orman İşletme Şefliği alanı 21 160,7 ha olup ormanlık alanı $16 \quad 207,4$ ha'dır. İşletme Şefliği içerisindeki "c", "cd", "d" meşcerelerinin toplam alanı 1 830,7 ha'dır.

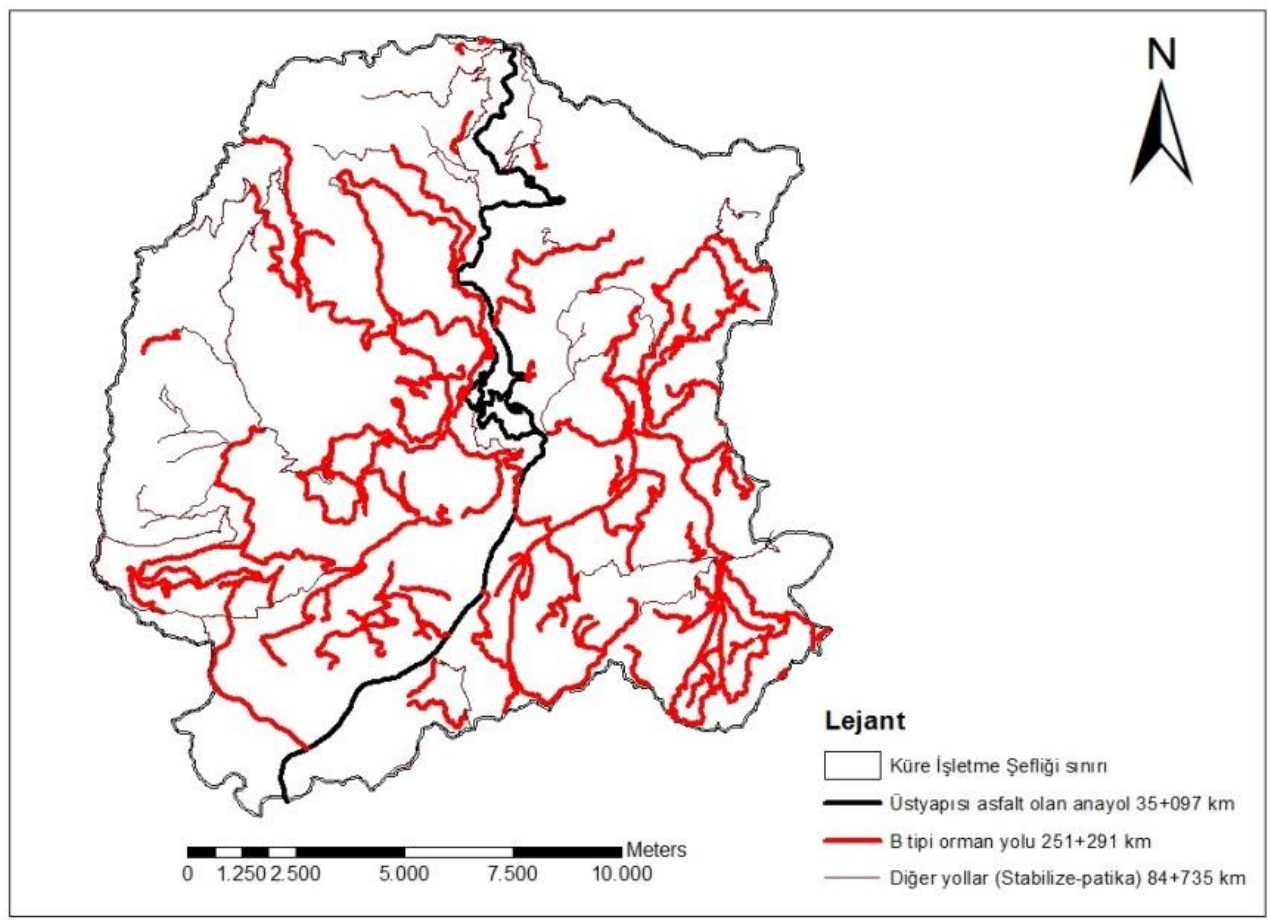

Şekil 4. Küre Orman İşletme Şefliği içerisindeki Ana ve B Tipi Orman Yolları Haritası 
Üst yapıs1 asfalt olan yolların her iki yanına 1000 m'lik bir tampon alan atıldığında bu alan içerisinde $54+689 \mathrm{~km} \mathrm{~B}$ Tipi orman yolu kalmaktadır. $\mathrm{Bu}$ alan içerisindeki "c", "cd", "d" çağındaki meşcere alanı 401,6 ha olup bu meşcerelerden boylu emvallerin çıkartılarak ulaşımının uzun nakliyat taşıtları ile sağlanabilmesi için $\mathrm{A}$ Tipi orman yoluna standartları yükseltilecek B Tipi orman yolu uzunluğu $18+401 \mathrm{~km}$ olmaktadır (Şekil 5).

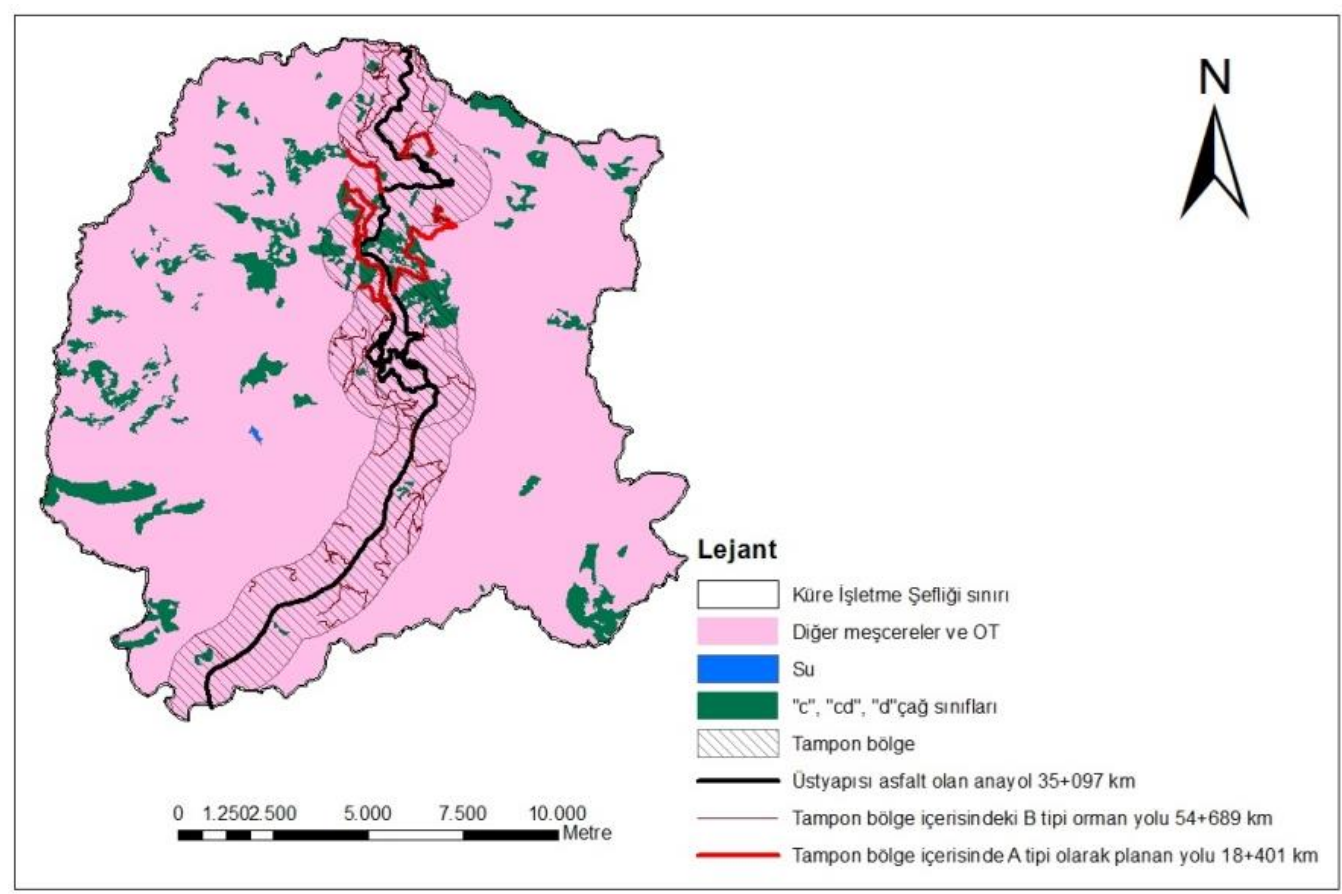

Şekil 5. Ana yoldan $1000 \mathrm{~m}$ uzaklıkta bulunan bütün gövde üretimi yapılabilecek meşcerelere ulaşımı sağlayan A Tipi orman yolu geçki önerisinin gösterir harita

Üst yapıs1 asfalt olan yolların her iki yanına 1500 m'lik bir tampon alan atıldığında bu alan içerisinde $85+619 \mathrm{~km} \mathrm{~B}$ Tipi orman yolu kalmaktadır. $\mathrm{Bu}$ alan içerisindeki "c", "cd", "d" çağındaki meşcere alanı 605,6 ha olup bu meşcerelerden boylu emvallerin çıartılarak ulaşımının uzun nakliyat taşıtları ile sağlanabilmesi için A Tipi orman yoluna standartları yükseltilecek B Tipi orman yolu uzunluğu $22+886 \mathrm{~km}$ olmaktadır (Şekil 6). 


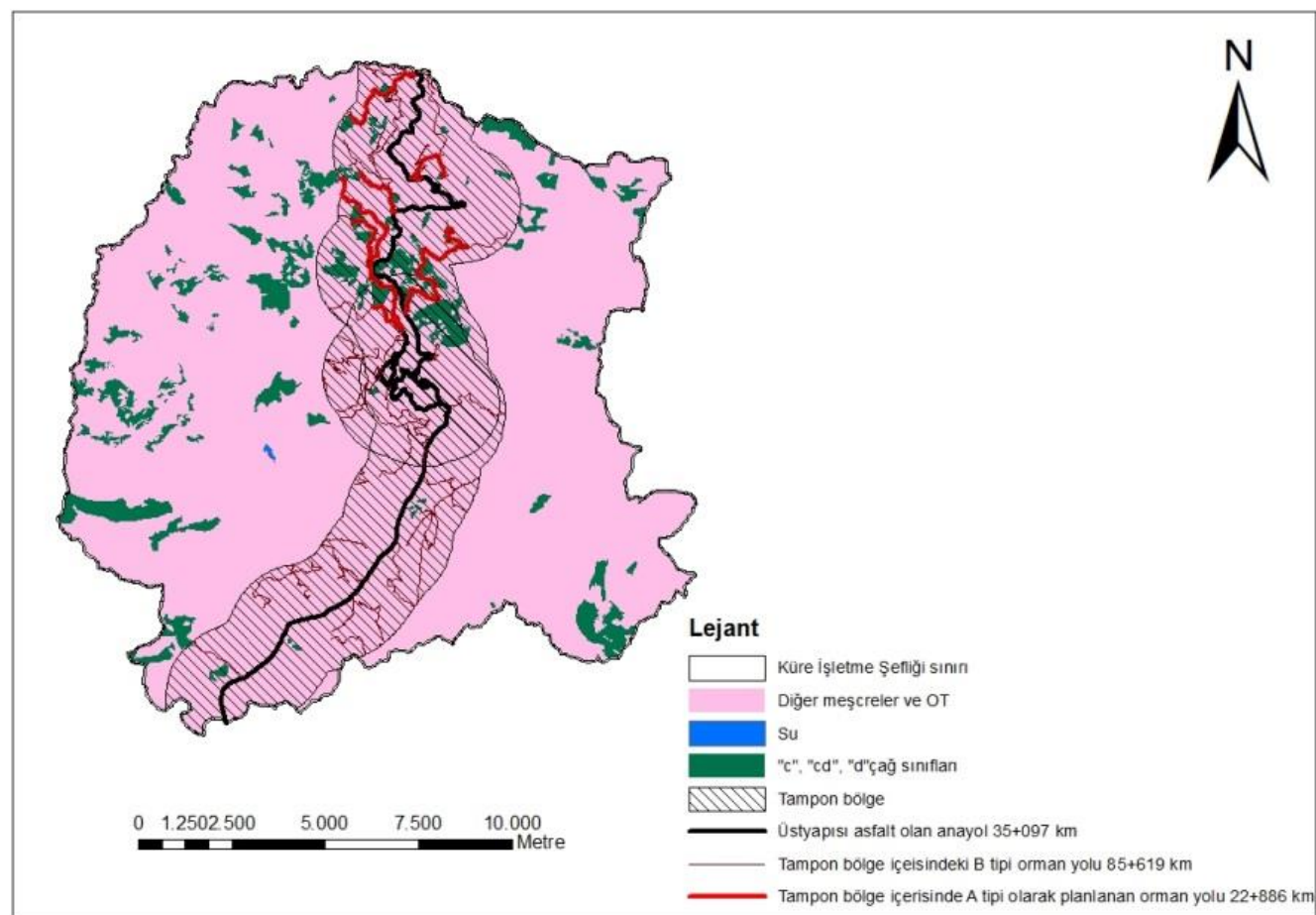

Şekil 6. Ana yoldan $1500 \mathrm{~m}$ uzaklıkta bulunan bütün gövde üretimi yapılabilecek meşcerelere ulaşımı sağlayan A Tipi orman yolu geçki önerisinin gösterir harita

Üst yapıs1 asfalt olan yolların her iki yanına 2000 m'lik bir tampon alan atıldığında bu alan içerisinde $117+734 \mathrm{~km} \mathrm{~B}$ Tipi orman yolu kalmaktadır. $\mathrm{Bu}$ alan içerisindeki "c", "cd", "d" çağındaki meşcere alanı 823,5 ha olup bu meşcerelerden boylu emvallerin çıkartılarak ulaşımının uzun nakliyat taşıtları ile sağlanabilmesi için A Tipi orman yoluna standartları yükseltilecek B Tipi orman yolu uzunluğu $29+351 \mathrm{~km}$ olmaktadır (Şekil 7).

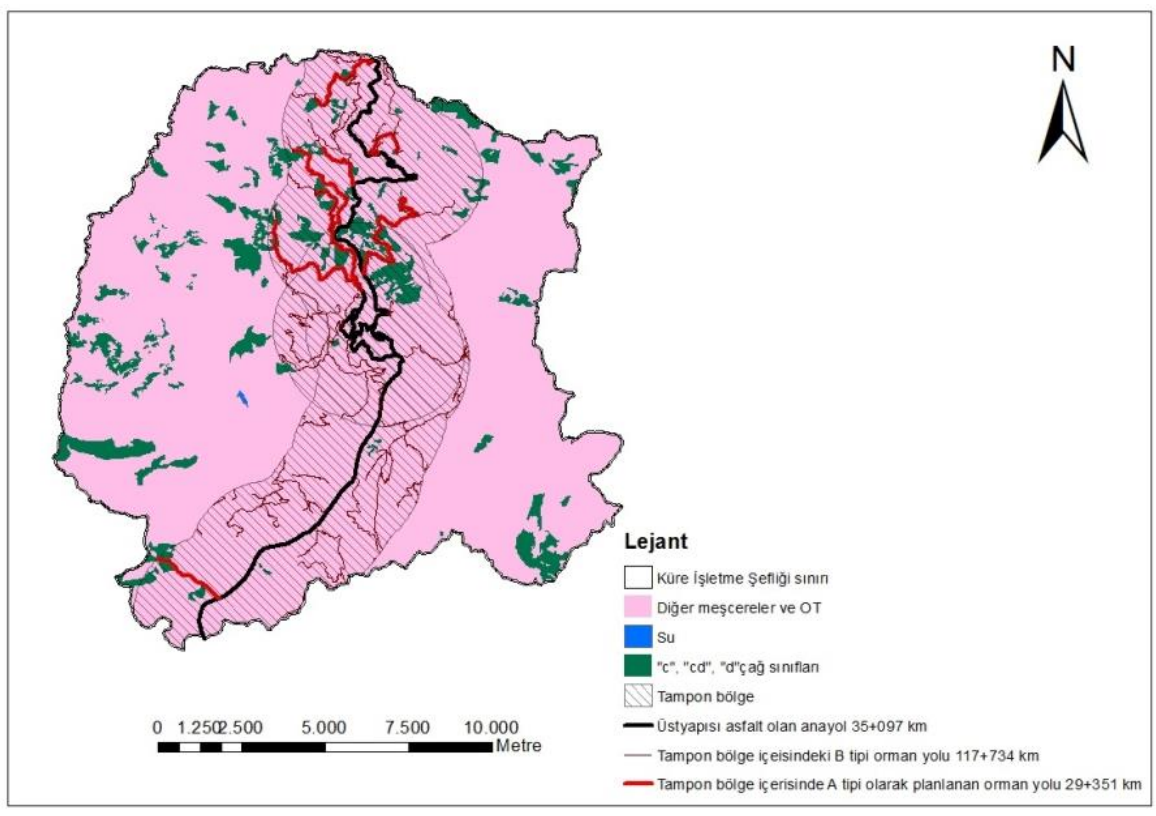

Şekil 7. Ana yoldan $2000 \mathrm{~m}$ uzaklıkta bulunan bütün gövde üretimi yapılabilecek meşcerelere ulaşımı sağlayan A Tipi orman yolu geçki önerisinin gösterir harita 


\section{Sonuç ve Öneriler}

Orman yol ağ1 şebekesinin optimal şekilde tesis edilmesi, orman kaynaklarının sürekliliğinin korunması ve orman ürünleri transportunun ülke ekonomisine olan katkısı için oldukça önemlidir.

$\mathrm{Bu}$ çalışmada Küre Orman İşletme Şefliğinde asfalt üstyapıya sahip anayol etrafında oluşturulan farklı genişlikteki tampon bölgeler içerisinde uzun, geniş ve yüksek yük kapasiteli taşıtların üzerinde hareket edebileceği A Tipi orman yol geçkileri planlanmıştır. Küre İşletme Şefliğinde her tampon bölge alanı için ayrı ayr1 planlanması önerilen A Tipi orman yol geçkilerinin uzunlukları ve güzergâhları ArcGIS ortamında haritalanmıştır. 251+291 km B Tipi orman yolu bulunan Küre Orman İşletme Şefliğinde;

- 1000 m tampon alan içerisinde kalan bütün gövde üretimine konu olabilecek meşcerelere ulaşım için $18+401 \mathrm{~km}$,

- 1500 m tampon alan içerisinde kalan bütün gövde üretimine konu olabilecek meşcerelere ulaşım için $22+886 \mathrm{~km}$,

- 2000 m tampon alan içerisinde kalan bütün gövde üretimine konu olabilecek meşcerelere ulaşım için $29+351 \mathrm{~km}$

A Tipi orman yolu geçkisi planlaması yapılmıştır (Tablo 2).

Tablo 2. Küre Orman İşletme Şefliğinde oluşturulan tampon alanlardaki "c" - "cd" - "d" çağ sınıfı alanları ve planlanan A Tipi Orman Yolu standartlarındaki orman yol geçkisi uzunlukları

\begin{tabular}{ccc}
\hline & $\begin{array}{c}\text { "c"-ccd"-“d” Çăg } \\
\text { sınıfi }\end{array}$ & $\begin{array}{c}\text { A Tipi orman yolu standardına } \\
\text { yükseltilecek B Tipi orman yolu uzunluğu }\end{array}$ \\
\hline $\mathbf{1 0 0 0}$ m'lik tampon bölge & $401,6 \mathrm{ha}$ & $18+401 \mathrm{~km}$ \\
\hline $\mathbf{1 5 0 0}$ m'lik tampon bölge & $605,6 \mathrm{ha}$ & $22+886 \mathrm{~km}$ \\
\hline $\mathbf{2 0 0 0}$ m'lik tampon bölge & $823,5 \mathrm{ha}$ & $29+351 \mathrm{~km}$ \\
\hline Toplam & $\mathbf{1 8 3 0 , 7}$ ha & \\
\hline
\end{tabular}

A Tipi olarak planlanacak orman yolları 292 Sayılı Tebliğ'de belirtildiği gibi platform genişliği $6 \mathrm{~m}$, hendek genişliği $1 \mathrm{~m}$ olup toplam genişliği $7 \mathrm{~m}$ olarak yapılmalıdır. $\mathrm{Bu}$ tip yolların tamamı $5 \mathrm{~m}$ genişlikte üst yap1 malzemesi ile kaplanmal1, asgari kurp yarıçap $35 \mathrm{~m}$ ve azami eğim $\% 10$ olmalıdır. Böylelikle uzun ve geniş olan tır tipi nakliyat araçları bu tip orman yolları üzerinde hareket edebilecektir.

1000 m'lik tampon alan içerisinde kalan "c" - "cd" - "d" çağ sınıfındaki meşcerelerin alanı 401,6 ha olup Küre Orman Isşletme Şefliği içerisindeki tüm "c" - "cd" - "d" çağ sinifi alanlarının (1830,7 ha) \%22'sine uzun, geniş ve yüksek yük kapasiteli taşıtlarının ulaşımı mümkün olabilmektedir.

1500 m'lik tampon alan içerisinde kalan "c" - "cd" - "d" çağ sınıfındaki meşcerelerin alanı 605,6 ha olup tüm ormanlık alan içerisindeki "c" - "cd" - "d" çă̆ sınıfi alanlarının (1830,7 ha) \%33'üne ulaşımın uzun, geniş ve yüksek yük kapasiteli taşıtlar ile sağlanabilecektir.
2000 m'lik tampon alan için ise bu bölgede içerisinde kalan "c" - "cd" - "d" çağ sinıfindaki meşcerelerin alanı 823,5 ha olup çalışma alanı sınırları içerisindeki tüm "c" "cd" - "d" çağ sınıfı alanlarının (1830,7 ha) $\% 45$ 'ine uzun, geniş ve yüksek yük kapasiteli taşıtlarının ulaşımı mümkün olabilmektedir.

Tablo 2'ye göre asfalt üstyapıya sahip yolların çevresinde 1500 m'lik tampon bölge oluşturulması durumunda bu alan içerisinde kalan "c" - "cd" - "d" meşcereleri tüm alandaki "c" - "cd" - "d" meşcerelerinin \%33'ünü olușturmaktadır. $\mathrm{Bu}$ alan içerisindeki $85+619 \mathrm{~km}$ B Tipi orman yolunun 22+886 km'si A Tipi orman yolu standartlarına yükseltilirse işletmenin karlılı̆̆ 1 açıssından doğru bir planlama olabileceği kanısına varılabilir.

Orman İşletme Şefliklerinde asfalt üstyapıya sahip yollara yakın bütün gövde üretimine konu olabilecek meşcerelerin belirlenmesi ile bu alanlardan ürün transportunda uzun-geniş ve yüksek yük kapasiteli tır tipi nakliyat araçlarının 
kullanımına uygun olabilecek A Tipi orman yolu geçkileri planlanabilecektir.

Planlanacak A Tipi orman yollarını kullanabilecek uzun, geniş, römorklu kamyon ve tırlar sayesinde;

- Normal uzunluktaki standart kamyonlara göre tek seferde daha fazla emval ormanlık alanlardan çıkarılabilecektir.

- Orman ürünlerinin tır tipi nakliyat araçları ile orman alanlarından çıkarılması ile ürünlerde daha az zayiat ve değer kaybı meydana gelecektir.

- Piyasanın zaman zaman ihtiyaç duyarak talep ettiği uzun boylu emvalin transportu mümkün olabilecektir.

- Uzun boylu emvallerin satışa konu olabilmesi ile işletmenin daha çok kazanç sağlaması söz konusu olacaktır.

- Dikili satış yöntemi ile yapılan ihalelerde yol kalitesinin yüksek olmasından dolayı ihale fiyatlarının, dolayısıyla işletme karının artması sağlanabilecektir.

- Bütün gövde metodu ile üretiminin yapılmasıyla birim zamanda iş verimi yükselecektir.

- İşçi sayısının azalmasıyla işletme karlılığı artacak, bunun yanında iş kazalarında azalmalar görülecektir.

- Kesim zamanı ile satış arasındaki süre kısalacak ve daha az harcanan zamanla beraber transport verimliliği de artacaktır.

- A Tipi orman yollarının yapım masrafları B Tipi orman yollarına göre daha yüksek olmakla beraber, A Tipi orman yollarının bakım giderlerinin B Tipi orman yollarına göre düşüktür. Bundan dolayı uzun vadede A Tipi orman yolları maliyet açısından avantajlıdır.

Yöntem bazında uygulanan bu çalışma, piyasanın bütün gövde talep durumunu karşılayacak şekilde planlanabilecek, üzerinde uzun-geniș ve römorklu tırların kullanılabileceği A Tipi orman yolu geçkisi planlama konusunda yol gösterici bir çalışma olup başka çalışmalar için geliștirilebilecektir.

\section{Kaynaklar}

Akgül, M. 2007. Kullanım fonksiyonlarına göre orman yollarının planlanması ve tasarımı üzerine incelemeler "Kanlıca Devlet Orman İşletmesi Örneği” Yüksek Lisans Tezi, İstanbul Üniversitesi Fen Bilimleri Enstitüsü, İstanbul

Anonymus 2002. BMP GUIDE Virginia's forestry best management practices for water quality, fourth edition, Virginia.

Anonim 2011a. Küre Orman İşletme Şefliği Yol Ağı Planı, Orman Ve Su İşleri Bakanlığı Orman Genel Müdürlüğ̈̈ OGM, Ankara.

Anonim, 2011b. Küre Orman İșletme Şefliği Amenajman Planı, Orman Ve Su İşleri Bakanlığı Orman Genel Müdürlüğü OGM, Ankara.

Arıcak, B., Çalışkan, E., Gümüş, S., Acar, H.H. 2007. Orman yollarının uzaktan algılama ve cbs ile planlanmasının değerlendirilmesi, TMMOB Harita ve Kadastro Mühendisleri Odas1 Ulusal Coğrafi Bilgi Sistemleri Sempozyumu, KTÜ, Trabzon.

Bayoğlu, S.1988. Üretim mekanizasyonu metotları ile orman yol şebekesi ilişkileri. Journal of the Faculty of Forestry Istanbul University (JFFIU) 38.3: 56-63.

Borre, K., and Larsson, R., 2011. Low speed maneuvering aids for long vehicle combinations.

Brooks R. M., Cetin M. 2013. Determination of the Influence of Vehicles Weight Ratio on the Initial Velocity Using the Accident Reconstruction Engineering Principles. International Journal of Emerging Technology and Advanced Engineering. 3(3), 927-931.

Cetin, M. 2015b. Evaluation of the sustainable tourism potential of a protected area for landscape planning: a case study of the ancient city of Pompeipolis in Kastamonu. International Journal of Sustainable Development \& World Ecology. Doi:10.1080/13504509.2015.1081651

Cetin M, Sevik H. 2016. Evaluating The Recreation Potential of Ilgaz Mountain National Park in Turkey. Environmental Monitoring and Assessment 2016; 188 (1): $52 . \quad$ DOI: 10.1007/s10661-015-5064-7.

Çağlar, S., and Acar, H.,H. 2005. Koller k300 orman hava hattı ile bölmeden çıkarmada çalışma verimi üzerine bir inceleme. Artvin Çoruh Üniversitesi Orman Fakültesi Dergisi 6.1: 113120.

Erdaş, O. 1997. Orman Yolları. Karadeniz Teknik Üniversitesi Orman Fakültesi, Cilt I., Yayın No:187/25.

Erdaș O., Acar H.H., Eker M. 2014.Orman Ürünleri Transport Teknikleri, Ktü Yayın No:233, Orman Fakültesi Yayın No:39,504s., KTU Basımevi Müdürlüğü, Trabzon. 
Giummarra, G. J., and Blanksby, C. R 367. 2006. Engineering requirements for logging truck operations on forest roads.

Görcelioğlu, E. 2004. Orman Yollar1-Erozyon İlişkisi. İÜ Orman Fakültesi Yayınları, (4460/476), 184.

Gulci, S., Akay, A. E. 2015. Assessment of ecological passages along road networks within the Mediterranean forest using GIS-based multi criteria evaluation approach. Environmental monitoring and assessment, 187(12), 1-13.

Gumus, S., Acar, H. H., Toksoy, D. 2008. Functional forest road network planning by consideration of environmental impact assessment for wood harvesting. Environmental monitoring and assessment, 142(1-3), 109-116

Hasdemir, M., Demir, M. 2000. Türkiye'de orman yollarını karayolundan ayıran özellikler ve bu yolların sinıflandırılması, İstanbul Üniversitesi Orman Fakültesi Dergisi, Seri B, Cilt 50, Sayı 2, s.85-96.

Melemez, K., et al. 2011.Orman yol ağ 1 planlarının sayısal ortamda üretilmesi (AntalyaDoyran İşletme Şefliği Örneği). I. Ulusal Akdeniz Orman ve Çevre Sempozyumu, 26-28 Ekim 2011, Kahramanmaraş

OGM 2008. Orman yolları planlaması, yapımı ve bakımı, 292 Sayılı Tebliğ, Ankara.

Öztürk, T. 2006. Türkiye'de odun üretiminin iş aşamaları. Journal of the Faculty of Forestry Istanbul University (JFFIU) 56.2 (2006): 109122.

Pentek, Tibor, et al.2007. Quality planning of forest road network-precondition of building and maintenance cost rationalization. Proceeding of Austro2007/FORMEC 07: Meeting the Needs of Tomorrows Forests-New Developments in Forest Engineering.

Potocnic, I.1996. The multiple use of forest roads and their classification, Biotechinical Faculty, Department Of Forestry, Ljubljna, Slovenia, 103-108

Tavşanoğlu, F.1973. Orman Transport Tesis Ve Taşıtları, Sermet Matbaası, İstanbul. 